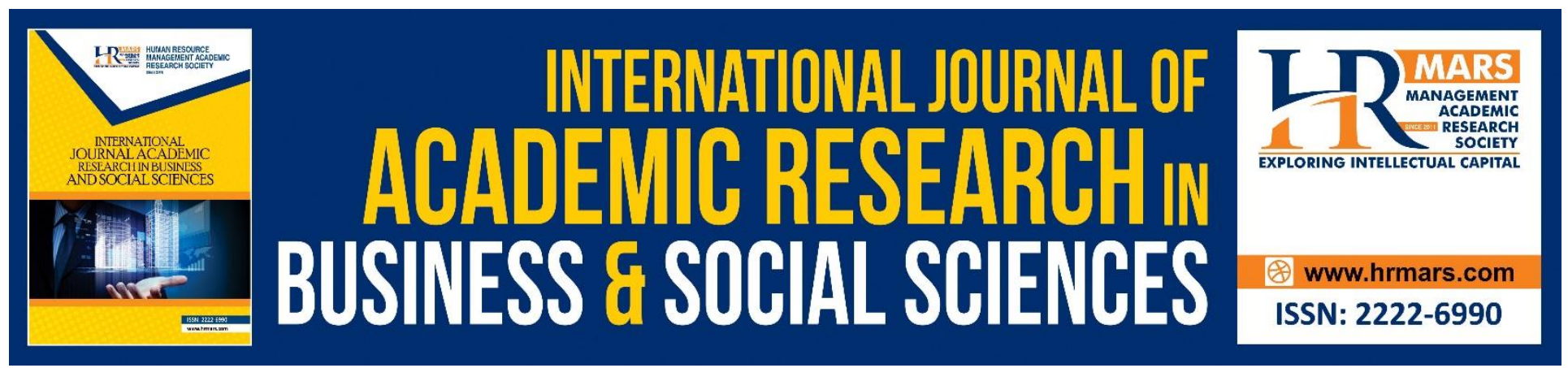

\title{
Effect of Knowledge Acquisition on Competitiveness of Savings and Credit Cooperative Societies in Trans Nzoia County, Kenya
}

Wycliffe Joseph Muchanji, Elizabeth Nambuswa Makokha

To Link this Article: http://dx.doi.org/10.6007/IJARBSS/v8-i9/4650

DOI: $\quad 10.6007 /$ IJARBSS/v8-i9/4650

Received: 06 August 2018, Revised: 27 August 2018, Accepted: 29 Sept 2018

Published Online: 15 October 2018

In-Text Citation: (Muchanji \& Makokha, 2018)

To Cite this Article: Muchanji, W. J., \& Makokha, E. N. (2018). Effect of Knowledge Acquisition on Competitiveness of Savings and Credit Cooperative Societies in Trans Nzoia County, Kenya. International Journal of Academic Research in Business and Social Sciences, 8(9), 716-734.

Copyright: (C) 2018 The Author(s)

Published by Human Resource Management Academic Research Society (www.hrmars.com)

This article is published under the Creative Commons Attribution (CC BY 4.0) license. Anyone may reproduce, distribute, translate and create derivative works of this article (for both commercial and non-commercial purposes), subject to full attribution to the original publication and authors. The full terms of this license may be seen at: http://creativecommons.org/licences/by/4.0/legalcode

Vol. 8, No. 9, September 2018, Pg. 716 - 734 http://hrmars.com/index.php/pages/detail/IJARBSS

Full Terms \& Conditions of access and use can be found at http://hrmars.com/index.php/pages/detail/publication-ethics 


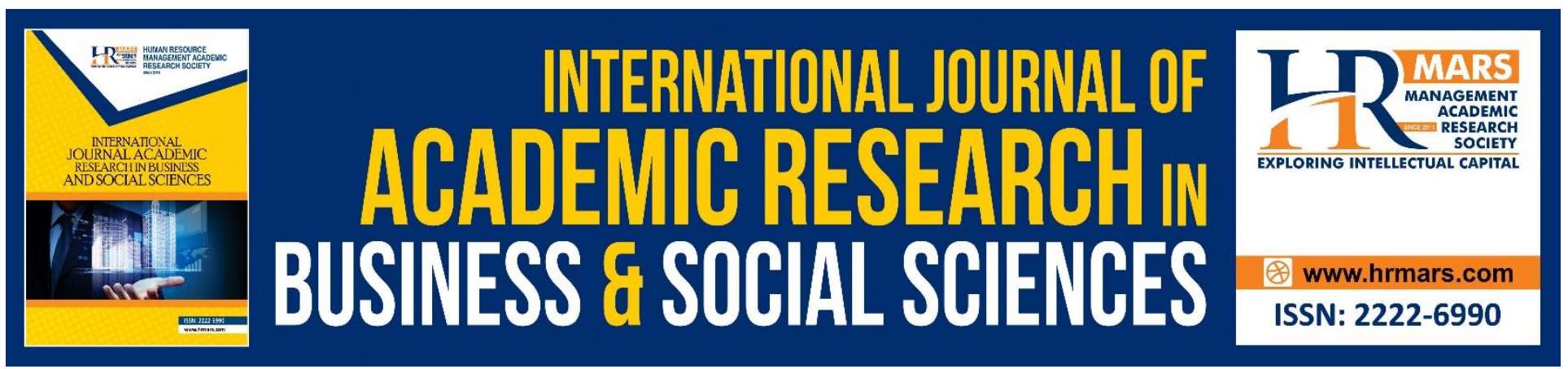

\title{
Effect of Knowledge Acquisition on Competitiveness of Savings and Credit Cooperative Societies in Trans Nzoia County, Kenya
}

\author{
Wycliffe Joseph Muchanji \\ Jomo Kenyatta University of Agriculture and Technology, P.O. Box 62000-00200, \\ Nairobi, Kenya, School for Human Resource Development Entrepreneurship and Procurement \\ Department \\ Email: wmuchanji@gmail.com
}

\begin{abstract}
Dr. Elizabeth Nambuswa Makokha
Jomo Kenyatta University of Agriculture and Technology, P.O. Box 62000-00200, Nairobi, Kenya, School for Human Resource Development Entrepreneurship and Procurement Department
\end{abstract}

\begin{abstract}
The cooperatives sector remains of great significance to the economic development of Kenya as it employs thousands of Kenyans, out of 261 Savings and credit cooperative societies in Trans Nzoia County, its only 65 of them that are vibrant, their poor performance has led to members' withdrawal at annual rate of $10 \%$. The purpose of the study was to determine the effect of knowledge acquisition on competitiveness of savings and cooperative societies in Trans Nzoia county. The study objective was to determine the effect of knowledge acquisition on competitiveness of savings and credit cooperative Societies in Trans Nzoia County. The study used descriptive survey research design. Target population for the study was drawn from employees of savings and credit cooperatives societies in Trans Nzoia County. The study targeted employees from the three main savings and credit cooperative sector operating in the County which included the Agricultural, industrial and the financial sector. The total target population comprised 1,174 respondents. The sample size from the management employees comprised 143 managers and 273 subordinate staff. The research technique used in collecting data was a structured questionnaire. The filled questionnaires were collected by the researcher, then coded and keyed into SPSS computer software and analyzed. Qualitative data was analysed thematically while quantitative data was analysed using descriptive statistical techniques which included frequencies and mean. The findings were presented using frequency distribution tables that gave record of a number of times a score or a response occurs. The study
\end{abstract}


finding indicated that respondents held that the firm develops and implements training plan annually. The study findings also indicated that there was a significant relationship between knowledge acquisition and competitiveness of savings and credit cooperative societies. The study concluded that organizational knowledge was the most important source of competitive advantage and is acquired and transferred within an organization by means of training. The study recommended that organizations should recognize advantage of knowledge by budgeting for employees training.

Keywords: Knowledge acquisition, Knowledge Management, Savings and Credit Cooperative Societies, Competitiveness.

\section{INTRODUCTION}

Zack (2015) argued that acquisition, capturing or gathering is bringing knowledge into the organization either through the generation of new knowledge through internal sources such as dayto-day experiences or staff expertise, or accessing valuable knowledge from external information sources and other organizations. Knowledge acquisition is a complementary capability that enhances a firm's absorptive capability to identify and acquire external information that is critical to its operations (Zahra \& George, 2015). A firm's "absorptive capacity" is critical to its innovative capacity. Absorptive capacity is a firm's ability to "recognize the value of new, external information, assimilate it, and apply it to commercial ends" (Cohen \& Leventhal, 1990). Darroch (2003) argued that knowledge acquisition relates to the location, creation or discovery of knowledge. The new knowledge in an organization has to either be invented internally or acquired from external sources. There are many sources of knowledge both internal and external for an organization to tap from (Werra et al. 2009). Internally, employees' individual capabilities, skills and experiences need to be discovered and exploited. Also, the analysis and understanding of various internal data and information are vital sources of knowledge that can be exploited. In the same way, externally, customers and channel members have knowledge that needs to be acquired by the organization for decision-making. Knowledge can also be acquired from other members of the external environment like competitors and the public (Petruzzelli et al. 2015). In Kenya, the need for competitive advantage in all types of organizations arises as organizations grow and competition intensifies. This case becomes true of the SACCO sector. In Kenya, current SACCO markets are saturated with similar products, decreased economies of scale and high competition. Lack of the right marketing knowledge, skills and strategies has made the situation worse and SACCO's are still struggling to grow market share. In addition, developing new products and services to enable SACCOs to prosper is a challenge (Ademba, 2013). For SACCOs to survive, prosper and achieve a sustainable competitive advantage, their managements need to consider some factors in their strategies and plans that can help in improving sales and increasing their dominance in their target markets including knowledge acquisition (Ademba,2014). KUSCCO (2015) states that, there are different challenges which include insufficient capital, competition from commercial banks, inefficient loan pricing strategies, and slow or lack of information technology adoption among others and there is need to address these challenges and strengthen the Kenyan cooperative movement since the sector has failed to document how effectively they manage their knowledge to give a competitive advantage. 


\section{Statement of the Problem}

Savings and Credit Co-operative Societies are the most widely adopted form of external financing for individual investors and private developers as well as micro and small enterprises due to their rapidly increasing role towards developing these enterprises. In Kenya, savings and credit co-operative societies contributes over $45 \%$ of GDP, it is estimated that at least one out of every two Kenyans directly or indirectly derives his /her livelihood from these kinds of cooperative movements. For cooperatives to survive, prosper and achieve a sustainable competitive advantage, their managements need to consider some factors in their strategies and plans that can help in improving sales and increasing their dominance in their target markets through proper knowledge management (Ademba,2015). The savings and credit cooperative societies movement in Kenya has faced numerous operational challenges due to sudden Government withdrawal from its previous extensive support and also due to the negative effects of a dynamic economic and business environment in the country. Small cooperatives on the other hand find it very hard to attract new business and compete in such an environment which means they lose many of their members to providers who are competitive (Ministry of cooperative development and marketing, 2013). The situation in most of these savings and credit cooperative societies is characterized by haphazard marketing strategies, lack of coherence, and lack of focus as required knowledge to manage these processes is inexistent. CGTC, County Cooperative Department (2017) reported that out of 261 cooperative societies in Trans Nzoia County, only 65 of them are vibrant, most of the cooperatives have few activities that they carry out collectively, the multipurpose cooperatives do not operate to reach a level of maximum returns and benefits to members, poor performance has led to members' withdrawal from some savings and credit cooperative societies at annual rate of $10 \%$, failure to save and repay loans has been an indicator of poorly performing savings and credit cooperative societies in the County which has been attributed to lack of competitiveness of the savings and credit cooperative societies. The literature available so far indicate that there has since been no studies conducted aimed at addressing the effect of knowledge acquisition on competitiveness of savings and credit cooperative societies. It is therefore against this background that the study aims to determine the effect of the knowledge acquisition on competitiveness of savings and credit cooperative societies In Trans Nzoia County, Kenya.

\section{General objective of the Study}

The general objective of this research study was to determine the effect of knowledge acquisition on competitiveness of savings and credit cooperative societies in Trans Nzoia County, Kenya .

\section{Conceptual Framework}

The conceptual framework illustrates the relationship between the independent variables namely training, innovation, research and development and test runs and the dependent variable competitiveness. The conceptual frameworks is supported by the resource based theory. 
INTERNATIONAL JOURNAL OF ACADEMIC RESEARCH IN BUSINESS AND SOCIAL SCIENCES Vol. 8, No. 9, Sept. 2018, E-ISSN: 2222-6990 @ 2018 HRMARS

Independent variables

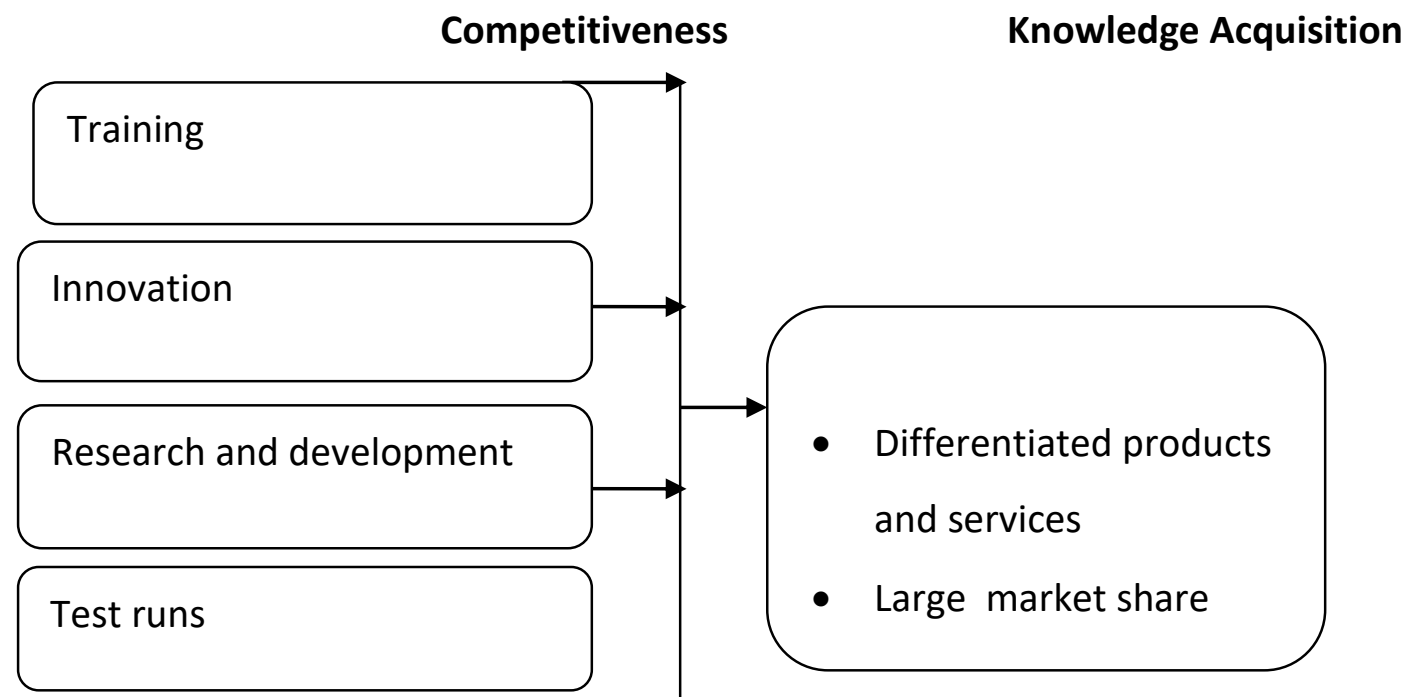

Figure 1.1 Conceptual Framework.

\section{Research Theory}

\section{Resource Based Theory}

Resource Based View perspective stresses that the resources of the company whether tangible or intangible like Brand name, assets, cash, customer loyalty, R\&D capabilities are an important firm resources that hold the potential for sustained competitive advantage (Liaw, 2014). The resource based view (RBV) is the basis for the sustainable competitive advantage which lies primarily in the application of a bundle of valuable tangible or intangible resources at the firm's disposal. Yee(2015) argued that for an organization to transform a short uncompetitive advantage into a sustained competitive advantage, it requires that these resources are heterogeneous in nature and not perfectly mobile. Effectively, this translates into valuable resources that are neither perfectly imitable nor substitutable without great effort. If these conditions hold, the bundle of resources can sustain the firm's above average returns According to this theory, a competitive advantage can be attained if the current strategy is value-creating, and not currently being implemented by present or possible future competitors. Although a competitive advantage has the ability to become sustained, this is not necessarily the case (Oates,2015).Sustainability in the context of a sustainable competitive advantage is independent with regard to the time frame. Rather, a competitive advantage is sustainable when the efforts by competitors to render the competitive advantage redundant have ceased. When the imitative actions have come to an end without disrupting the firm's competitive advantage, the firm's strategy can be called sustainable. This is in contrast to views of others that a competitive advantage is sustained when it provides above-average returns in the long run (Barther,2015). An organization which is serious about competing in the fast changing markets and technology must make things happen, it must innovate. If it does not innovate, it risks being overtaken by competitors, sometimes a business underestimates the competitive challenges it faces, the risk of this happening is high when 
INTERNATIONAL JOURNAL OF ACADEMIC RESEARCH IN BUSINESS AND SOCIAL SCIENCES Vol. 8, No. 9, Sept. 2018, E-ISSN: 2222-6990 @ 2018 HRMARS

competitor's react or potential challenges in much the same way. Since most NGOs offer similar products and services, they continually search for a competitive advantage that will attract new donors and retain the existing ones for their programs. In this regard much emphasis have been placed on building innovative organizations and the management of the strategic process, as essential elements of organizational survival (Brown, 2014). Competitive strategies can be transformational, radical or incremental depending on the effect and nature of the change. (Liaw, 2014) suggests that competitive strategies do not have to be breakthroughs or paradigm shifting; Firms, according to the resource-based approach, compete according to their different capabilities. Strategies to cope with a changing competitive environment are associated with the firm's capabilities. The resource based theory argues that competitive advantages lie in the heterogeneous firm specific resources possessed by the firm (Wernerfelt, 2016). The ability to be competitive is increasingly viewed as the single most important factor in developing and sustaining competitive advantage (Tidd, 2016). It is no longer adequate to do things better, it's about doing new and better things (Slater \& Narver, 2015). The resource based view is applicable in this study since it explains its ability to deliver sustainable competitive advantage when resources are managed such that their outcomes cannot be imitated by competitors which ultimately creates a competitive barrier.

\section{Empirical Review}

Chweya, et al. (2014) conducted a study on knowledge management practices and its effect on firm performance. The overall objective of this study was to analyze the effects of knowledge management practices on commercial banks' performance in Kisumu city in Kenya. The study sought to establish the effect of knowledge creation and knowledge sharing on organizational performance and determine the relationship between organizational performance. The study found that there was a significant relationship between knowledge creation and organizational performance. A significant positive relationship also existed between organizational performance anknowledge sharing. The study concluded that effective knowledge management promotes knowledge creation to maintain customer satisfaction and organizational performance. The current study is different as it focused on the effect of knowledge acquisition among savings and credit cooperative sector in Trans Nzoia County. Islam, Low and Hasan (2011) studied knowledge management practices and organizational effectiveness, the study investigated the relationship between knowledge management practices and organizational effectiveness in commercial banks operating in Bangladesh. In order to obtain primary data, questionnaire survey was conducted to find out the general practices of knowledge management in Bangladeshi banks, which was administrated to the managerial staff. A knowledge management process model was developed from the previous literature and tested. Knowledge management practices were classified under knowledge conversion, application and protection. The result indicated that knowledge management practices have significant influence over organizational effectiveness. This study focused knowledge acquisition among savings and credit cooperative sector in Trans Nzoia County.It used descriptive survey design and data was collected from both all employees in cooperative sector in the study area. Gholami, Asli, Nazari-Shirkouhi and Noruzy(2013) conducted a study to investigate the influence of knowledge management practices on organizational performance. The aim of this study was to investigate the influence of knowledge management practices on organizational performance in small and medium enterprises (SMEs) using structural 
INTERNATIONAL JOURNAL OF ACADEMIC RESEARCH IN BUSINESS AND SOCIAL SCIENCES Vol. 8, No. 9, Sept. 2018, E-ISSN: 2222-6990 @ 2018 HRMARS

equation modeling. A number of 282 senior managers from these enterprises were chosen using simple random sampling and the data were analyzed with the structural equation model. The results showed that knowledge storage, knowledge creation, knowledge sharing and knowledge implementation had significant factor loading on knowledge management. The results of this study suggested that knowledge management practices directly influence the organizational performance of SMEs. However, this study considered knowledge acquisition for both management and subordinate staff in the savings and credit cooperative sector in Trans Nzoia County. Rudez (2010) studied knowledge management in the hotel industry before and after the entry in the EU: The Case of Slovenia. It explored the changes in knowledge management between 2003 and 2006; that is before and after Slovenia entered the EU. The research revealed a progress in this period of time in knowledge management goals definition, transformation of not-owned into owned knowledge, inclusion of knowledge management in business reports, identification and elimination of the gaps between planned and actual knowledge. The current study is different as it focuses on the effect of knowledge acquisition on the competitiveness of savings and credit cooperative sector in Trans Nzoia County. Audretsch, Bonte and Keilbach (2014) carried out a study impact on knowledge diffusion and economic performance. The study developed two hypotheses: First, regional innovation efforts have a positive impact on regional knowledge based entrepreneurial activity. Second, knowledge based entrepreneurship positively affects regional economic performance. The study tested these hypotheses using county level data from West Germany, employing a structural equation model to analyze the relationships between latent variables. The empirical analysis provided evidence supporting both hypotheses. In particular, the results suggested that innovation efforts have an indirect effect on economic performance via entrepreneurship. This indirect effect was however neglected in existing empirical studies focusing on the direct effect of innovation on economic performance. However, the current study is different in terms of variables considered, location of the study which is Kenya and descriptive statistics was used in data analysis. Ngwiri, Mukulu and Mbuthia (2016) carried out a study on influence of knowledge technology transfer on the growth of micro and small catering enterprises in Nairobi County, Kenya. The research gathered information on the influence of technology transfer of production skills, knowledge on the growth of MSEs in terms of output, sales volume, profit and assets within the catering sector in the hospitality industry in Nairobi County. The study was conducted using survey method of data collection with both qualitative and quantitative approach. There was a total population of 11,162 licensed Catering MSEs in Nairobi County. A total of 384 respondents were picked through random sampling. Data was collected using a questionnaire with both closed and open ended questions. Interview guide was used in carrying out interviews. The data obtained in the study was analyzed using descriptive statistics such as means, frequencies and standard deviation. Inferential statistics used in the study included correlation and multiple regressions in order to determine the relation between the independent and dependent variables. Correlation technique was used in the study to analyze the degree of relationship between the independent and dependent variables while logit regression analysis was used to determine the effect of technology transfer on knowledge. Data was also subjected to factor analysis. The Binomial Logistic Regression was also used to analyze the data. Statistical package for social sciences (SPSS) Version 22 was used to run the data. Data were presented by use of frequency distribution tables, bar graphs and pie charts. The study established that transfer of production skills, 
equipment, knowledge and processes leads to the growth of micro and small catering enterprises in Nairobi County. Growth was measured in form of profit margin, increase in employees, increase in customers, enlargement in firm size and enhancement in quality of products and services. The study concluded that technology transfer of knowledge had an influence on the growth of micro and small catering enterprises. The study recommendations were: inclusion of more females in micro and small catering enterprises where the government offers incentives to female entrepreneurs through waiver of business license fees, government should initiate special capitation through budgetary allocations to cushion micro and small catering enterprises from collapse due to financial constraints and all firms should be encouraged to adopt the new and latest technology transfer in their businesses. This study considered the effect of knowledge acquisition on competitiveness of savings and credit cooperative in Trans Nzoia County. Nyongesa, Namusonge and Ng'eno (2016) carried out a study on the influence of strategic technical knowledge capability on performance of vendor managed retail firms in Nairobi County, Kenya. The objective of this study was to determine the extent to which strategic technical knowledge contributes to performance of the vendor managed retail medium and large supermarkets. To achieve this objective the study adopted a descriptive survey. The study population of this study comprised the medium and large sized supermarkets in Nairobi County. According to business licensing department at the Nairobi County, there are 15 medium sized supermarkets and 43 large sized supermarkets in Nairobi County. The target population included the senior managers in these supermarkets. The findings were presented using tables and charts. A multiple linear regression analysis was used in analysis. Strategic technical knowledge capability was found to be significant at $95 \%$ confidence level. Strategic technical knowledge capability was also found to be significantly and positively affecting vendor managed retail firms' performance. The study findings led the researcher to conclude that strategic technical knowledge capability contributes to performance of the vendor managed retail firms. However the current study is different as it focused on effect of Knowledge acquisition on the competitiveness of savings and credit cooperatives in Trans Nzoia County.

\section{Research Methodology}

The study adopted descriptive survey research design. Kothari and Garg (2014) posit that a research design is to state the conceptual structure within which research would be conducted. Research designs can be used to collect, analyse, and interpret data using quantitative and qualitative research. Descriptive Survey Design, according to Creswell (2012), may be used when one seeks to describe trends in a large population of individuals or even certain occurrences. Survey designs are procedures in research in which one can administer a survey or questionnaire to a small group of people (called the sample) to identify trends in attitudes, opinions, behaviours, or characteristics of a large group of people (called the population). This study applied descriptive survey research design. Lavaca's (2013) describes a descriptive survey research design as a systematic research method for collecting data from a representative sample of individuals using instruments composed of closed-ended and/or open-ended questions, observations, and interviews. This design enabled the researcher to answer the research questions. 
INTERNATIONAL JOURNAL OF ACADEMIC RESEARCH IN BUSINESS AND SOCIAL SCIENCES

Vol. 8, No. 9, Sept. 2018, E-ISSN: 2222-6990 @ 2018 HRMARS

\section{Population}

A population is considered to be any group of people, events, or items that are of interest to the researchers that they wish to investigate (Kothari, 2016). According to Uma Sekaran (2014) and Gujarati and Sangetha( 2016) a target population is a complete set of individual, cases or objects with some common observable characteristics. The target population for the study will be drawn from employees of Savings and credit cooperative societies in Trans Nzoia County. The study targeted employees from the three main savings and credit cooperative societies operating in the County which include the agricultural, industrial and the financial sector. The target population of the study is shown in Table 1.1.

Table 1.1: Target Population

\begin{tabular}{lcll}
\hline SACCOS & $\begin{array}{l}\text { Numberof } \\
\text { SACCOS }\end{array}$ & $\begin{array}{l}\text { Number of } \\
\text { management Staff }\end{array}$ & $\begin{array}{l}\text { Numberof } \\
\text { emplovees }\end{array}$ \\
\hline Agricultural & 27 & 96 & 367 \\
Financial & 25 & 80 & 420 \\
Industrial & 13 & 51 & 160 \\
Total & $\mathbf{6 5}$ & $\mathbf{2 2 7}$ & $\mathbf{9 4 7}$ \\
\hline
\end{tabular}

\section{Sample Size and Sampling Procedures}

The sample size of the study was calculated using the formula below as recommended by Fisher et al. (2003):

$\underline{\mathrm{N}}$

$\left(1+\mathrm{e}^{2} \mathrm{~N}\right)$

Where e is the confidence interval of $95 \%$ or $5 \%$

Where $\mathrm{N}=1174$

$e=5 \%$

$$
\frac{1174}{\left(1+.05^{2} * 1174\right)}=299
$$

The sample size from the employees thus comprised of 299 respondents.

The sample size of the study is shown in Table 1.2.

Table 1.2: Sample Size

\begin{tabular}{llll}
\hline SACCOS & $\begin{array}{l}\text { Number of } \\
\text { management } \\
\text { employees }\end{array}$ & $\begin{array}{l}\text { Numberof } \\
\text { subordinate } \\
\text { employees }\end{array}$ & Total \\
\hline Agricultural & 24 & 94 & 118 \\
Financial & 20 & 107 & 127 \\
Industrial & 13 & 41 & 54 \\
Total & $\mathbf{5 7}$ & $\mathbf{1 5 2}$ & $\mathbf{2 9 9}$ \\
\hline
\end{tabular}

The study employed a stratified sampling method to achieve the desired sample sizes from the various sub-sets in the population. The population was stratified in three types of savings and credit cooperative societies in the county that is agricultural, financial and industrial savings and credit 
INTERNATIONAL JOURNAL OF ACADEMIC RESEARCH IN BUSINESS AND SOCIAL SCIENCES Vol. 8, No. 9, Sept. 2018, E-ISSN: 2222-6990 @ 2018 HRMARS

cooperative societies. Purposive sampling was employed to pick the management employees while simple random sampling was employed to pick the employees of the company.

\section{Data Collection Instruments}

The data collection instruments used in data collection was the questionnaire for both the savings and credit cooperative societies employees. Through questionnaires, the researcher gathered data from the employees in the savings and credit cooperative societies. The questionnaires was closed ended question which enhanced standardization by creating the same frame for all respondents and required less effort and facility with words (Welman \& Kruger, 2003). Nsubuga (2000) affirms the use of closed ended questions because they are easy to administer and fill out, besides they help the respondents' mind to be on the subject and facilitate the process of tabulation and analysis. Each item in the questionnaire was developed to address a specific objective and research question of the study.

\section{Data Collection Procedures}

National Statistician's Guidance (2009) indicated that data collection procedures are the processes to be followed to access quality data by showing the authorities to be contacted for permissions to get adequate assurance of the quality of data to be collected from respondents. The researcher sought for authority letter from Jomo Kenyatta University of Agriculture and Technology confirming that the researcher is a Master of Business Administration candidate with the university conducting an academic research. The researcher requested permission from Trans Nzoia County Cooperative office to conduct research on cooperative societies registered with them. The questionnaires were administered by four research assistants.

\section{Pilot Test}

Nunes, et al. (2010) argued that pilot studies were instrumental in the framing of questions, collection of background information, refinement of a research approach or tailoring efficient research instruments. The pilot study was pre tested on a sample of 30 members of cooperative societies who were not included in the study sample but were part of the sampling frame.The number of savings and credit cooperative societies members who participated in the pilot study from each sector were as follows; industrial,10, agricultural 10 and financial savings and credit cooperative societies 10 translating to $10.3 \%$ of the target population used in the study. Simon (2011) argued that a pilot study sample size between $10-20 \%$ of the sample used in a study was representative. The pretesting of research instruments helped to point out questions that were difficult to understand, those that could be interpreted differently by different people as well as those that were similar. After the pre-testing, improvements were made on the research instruments. Validity and reliability were two important characteristics of behavioural measure and are referred to as psychometric properties (Berk, 2009).Instruments of the research were presented to savings and credit cooperative societies not included in the sample for piloting to ensure content clarity. Upon completion of the pilot study, the data was reviewed and the items that were not clear modified accordingly. During the piloting, both validity and reliability was tested. 
INTERNATIONAL JOURNAL OF ACADEMIC RESEARCH IN BUSINESS AND SOCIAL SCIENCES

Vol. 8, No. 9, Sept. 2018, E-ISSN: 2222-6990 @ 2018 HRMARS

\section{Validity of Research Instrument}

This is the success of a scale in measuring what it sets out to measure so that differences in individual scores can be taken as representing true differences on the characteristics under study (Koul,2012). This research adopted content validity to measure the validity of the instruments to be used. Content validity enabled data collected to be reliable in representing the specific content of a particular concept.

\section{Reliability Of Research Instrument}

Reliability refers to extent to which a measurement instrument is able to yield consistent results each time it is applied under similar conditions. It is the constituent of a measurement device that causes it to yield similar outcome or results for similar inputs. Statistically, reliability is defined as the percentage of the inconsistency in the responses to the survey that is the result of differences in the respondents. This implies that responses to a reliable survey will vary because respondents have different opinions, not because the questionnaire items are confusing or ambiguous. To ensure reliability of the questionnaires, a pilot study was carried out in SACCOS that were not to be part of the main study. This SACCOs used for piloting because they share similar conditions. The variables were tested for reliability by computing the Cronbach alpha where reliability coefficients around 0.90 were considered excellent, values around 0.80 as very good and values of around 0.70 as adequate (Koul, 2005). The piloting of the questionnaire was carried out in a similar sample but to be excluded from the study to identify faults which was used to improve reliability. The Cronbach alpha for reliability was 0.85

\section{Data Processing and Analysis}

Once the questionnaires were collected by the researcher, they were coded and keyed into SPSS computer software and analyzed. Initially screening of data was done. Data were based on the objectives and research questions of the study. Qualitative data were analysed thematically while quantitative data collected were analysed using descriptive statistical techniques which included frequencies percentages and mean. The findings were presented by use of frequency distribution tables that gave record of a number of times a score or a response occurs. Pearson Correlation Analysis was used in this research to examine the linear association among the independent variables and dependent variable. The purpose was to check the strength of the correlation relationship and to prevent multi co linearity problem. The correlation analysis was used to give correlation coefficients between the four independent variables measured using 5 point-item likert scales. The correlation coefficients indicated the strength of the association between the variables. A coefficient was considered significant when the $p$-value was less than 0.05. (Bryman, A. and Cramer, D., 1997) in (Boon and Arumugam, 2006) suggest 0.80 instead of 0.90 as the threshold.

\section{Discussion of Findings}

The study targeted 299 respondents who participated in the study but 180 responded to the questionnaires. This gave a response rate of $60.20 \%$ which was considered suitable for the study. The demographic information of the respondents is in Table 1.3 
INTERNATIONAL JOURNAL OF ACADEMIC RESEARCH IN BUSINESS AND SOCIAL SCIENCES

Vol. 8, No. 9, Sept. 2018, E-ISSN: 2222-6990 @ 2018 HRMARS

Table 1.3: Demographic Information Of The Respondents.

\begin{tabular}{lll}
\hline Gender & $F$ & $\%$ \\
Male & 98 & 54.44 \\
Female & 82 & 45.56 \\
Total & 180 & 100 \\
Age & 30 & 16.67 \\
$18-29$ years & 60 & 33.33 \\
30-39 year & 75 & 41.67 \\
40-49 years & 15 & 8.33 \\
Over 51 years & 180 & 100 \\
Total & & \\
Employment & 60 & 33.33 \\
below 5 years & 70 & 38.88 \\
Between 5-10 years & 50 & 27.78 \\
10yrs and above & 180 & 100 \\
Total & & \\
Education level & 30 & 16.67 \\
Certificate & 40 & 22.22 \\
Diploma & 70 & 38.89 \\
Undergraduate & 40 & 22.22 \\
Masters & 180 & 100 \\
Total & & \\
\hline
\end{tabular}

The study findings on gender of the respondents showed that $54.44 \%$ were males while 45.56 were female. This shows that the study managed to collect data from both genders and their opinions were represented in the study. The study results on the age of respondents indicated that $16.67 \%$ of the respondents were aged $18-29$ years; $33.33 \%$ were in between $30-39$ years age bracket; $41.67 \%$ were between $40-49$ years and $8.33 \%$ were over 51 years. This implies that majority of the respondents were aged between 40-49 years and that the study collected data from all the age brackets represented in the study. The study findings on employment of respondents indicated that $33.33 \%$ were employed below 5 years; $38.88 \%$ of the respondents were employed between 5-10 years and $27.78 \%$ respondents were employed for over 10 years. This implies that majority of the respondents were employed between 5-10 years and therefore had more skills and work experience in employment. The study findings on the education level indicated that $16.67 \%$ were certificate holders; $22.22 \%$ of the respondents were diploma graduates;33.89\% were undergraduates and 22.22 $\%$ of the respondents had acquired their masters in education. This implies that the respondents were knowledgeable and therefore understood the study questions and this could be interpreted to mean that they gave a true and fair view of the study questions. 
INTERNATIONAL JOURNAL OF ACADEMIC RESEARCH IN BUSINESS AND SOCIAL SCIENCES Vol. 8, No. 9, Sept. 2018, E-ISSN: 2222-6990 @ 2018 HRMARS

Factor loading for the effect of knowledge acquisition on competitiveness of saving and credit cooperative societies. The findings are presented in Table 1.4

Table 1.4: Factor Loading For The effect of knowledge acquisition on competitiveness of saving and credit cooperative societies

$$
\text { Component Matrix }{ }^{a}
$$

The firm has a R \& D center for developing new knowledge.

The firm innovativeness is rated at over $90 \%$.

The firm develops and implements training plan annually.

The firm conducts test runs for new

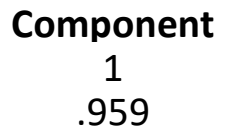

.859

.726

.648
Remarks

Retained

Retained

Retained

Retained

Extraction Method: Principal Component Analysis.

a. No components extracted.

Factor loading from the factor analysis revealed that all four items where retained; The firm has a $R$ \& D center for developing new knowledge (0.959), The firm innovativeness is rated at over $90 \%$ (0.859), the firm develops and implements training plan annually $(0.726)$ and The firm develops and implements training plan annually (0.648).

\section{Descriptive Statistics}

Table 1.5: The effect of knowledge acquisition on competitiveness of saving and credit cooperative societies

\begin{tabular}{|c|c|c|c|c|c|c|c|}
\hline & & SA & $A$ & UD & $D$ & SD & Mean \\
\hline $\begin{array}{r}\text { The firm develops and implements } \\
\text { training plan annually }\end{array}$ & $\begin{array}{l}\mathrm{F} \\
\%\end{array}$ & $\begin{array}{l}92 \\
50.3\end{array}$ & $\begin{array}{l}47 \\
25.7\end{array}$ & $\begin{array}{l}15 \\
8.2\end{array}$ & $\begin{array}{l}18 \\
9.8\end{array}$ & $\begin{array}{l}8 \\
4.4\end{array}$ & $\begin{array}{l}4.094 \\
81.8\end{array}$ \\
\hline $\begin{array}{r}\text { The firm innovativeness is rated at over } \\
90 \%\end{array}$ & $\begin{array}{l}F \\
\% \\
F\end{array}$ & $\begin{array}{l}69 \\
37.7 \\
56\end{array}$ & $\begin{array}{l}48 \\
26.2 \\
43\end{array}$ & $\begin{array}{l}31 \\
16.9 \\
30\end{array}$ & $\begin{array}{l}22 \\
12 \\
32\end{array}$ & $\begin{array}{l}10 \\
5.5 \\
19\end{array}$ & $\begin{array}{l}3.3 \\
66 \\
3.47\end{array}$ \\
\hline $\begin{array}{l}\text { The firm has a R \& D center for } \\
\text { developing new knowledge }\end{array}$ & $\mathrm{F}$ & 56 & 23.5 & 16.4 & 17.5 & 10.4 & 69.44 \\
\hline \multirow{2}{*}{$\begin{array}{l}\text { The firm conducts test runs for new } \\
\text { products }\end{array}$} & $\mathrm{F}$ & 47 & 41 & 32 & 35 & 25 & 3.28 \\
\hline & $\%$ & 25.7 & 22.4 & 17.5 & 19.1 & $13 . .7$ & 65.54. \\
\hline
\end{tabular}

The study findings indicated that $81.80 \%$ (mean=4.094) of the respondents held that the firm develops and implements training plan annually. The implication of this finding was that trainings was generally accpted among organizations as a means to make employeees acquire knowlege for an organization to be competitive. The study results also imply that academic training and formal training acquired in school alone is not sufficient to enhance organizational effectiveness to a greater level because not all such knowledge obtained from the training in school is properly transferred and applied to the organization. The study also found that $69.44 \%$ (mean=3.47) held that the firm has a research and development center for developing new knowledge. The implication of this outcome showed that new knowlege is developed to make the organization more competitive. The study also 
INTERNATIONAL JOURNAL OF ACADEMIC RESEARCH IN BUSINESS AND SOCIAL SCIENCES Vol. 8, No. 9, Sept. 2018, E-ISSN: 2222-6990 @ 2018 HRMARS

showed that $66.00 \%$ (mean=3.30) of the respondents held that the firm innovativeness is rated at over $90 \%$ and $65.54 \%$ (mean $=3.28$ ) held that the firm conducts test runs for new products. The results imply that new product development is phased accordingly to make it easier to increase the organizations clients. The study finding agrees with Chweya et al. (2014) who argued that knowledge acquisition enhances organizational performance. In addition, the study findings is in agreement with Abd,Imm,Muraliand Wong(2013)who found that training employees to acquire individual/managerial skills and process skills helps in improving organizational effectiveness; knowledge application and knowledge protection interact with individual/managerial skills training to improve organizational effectiveness and knowledge acquisition interacts with process skills training to enhance organizational effectiveness. Ruggles (2014) added that even if the firm is highly automated, it needs knowegeable people to program the machines which rely heavily on human at the point of consumption or transaction. Further, the findings agree with Yahya and Goh (2013) who argued that even though firms should recruit staff with the skills needed, thereafter the firm needs to make further investment in its staff to achieve competitive advantages. If the firm does not act to train its staff, it can only regress to a less competitive position (Argyris, 2017). Aroge (2014) agreed that organizational training presents a prime opportunity to expand the knowledge base of all employees, but many employers find the development opportunities expensive. Despite the potential drawbacks, training and development provides both the company as a whole and the individual employees with benefits that make the cost and time a worthwhile investment. According to Fokuo, Boakye and Kwaning (2014) agreed that training gives the employee a greater understanding of their responsibilities within their role, and in turn build their confidence. This confidence will enhance their overall performance and this can only benefit the company. Employees who are competent and on top of changing industry standards help your company hold a position as a leader and strong competitor within the industry. Gamage and Imbulana, L. (2013) agreed that a training program allows an organization to strengthen those skills that each employee needs to improve and helps reduce any weak links within the company who rely heavily on others to complete basic work tasks. Providing the necessary training creates an overall knowledgeable staff with employees who can take over from one another as needed, work on teams or work independently without constant help and supervision from others. On the contrary the study findings disagreed with Lennick (2014) who argued that training on organizational competitiveness showed that employees trained in a certain field can only perform task in that field only. Formal training tends to be that people can only do one task and they are not trained to multitask or handle multiple areas of a workplace. As result, when a critical expertise is lost the process can suffer. Additionally, workers under training in an organization don't have a wide array of applicable skills so it becomes hard for them to adapt to new function or need in the organization, as a result unemployment is a significant when a company has to shut down a factory or assemble line since many of the laid-off workers usually have a hard time to adjust to anew occupation. Mutandwa (2011) in noted that training as the organization grows in size and complexity, it is no longer possible for one manager to oversee all of the workers, so workers are assigned to new managers based on some overall plan. Most conventional libraries and information centers' such as academic, public and special libraries belonging to large organizations also operate this system. Most organizations use multiple bases of departmentalization in different levels. This leads to high competitiveness by workers, when an 
employee is satisfied with what he does he will in turn give his best toward the attainment of the general goal of the organization.Clark(2013) agreed that training is a method of production where by an entity focuses on the production of a limited scope of goods to gain greater degree of efficiency. Training is therefore the basis of global trade as few countries have enough production capacity to be completely self sustaining. Scott (2015) agreed that training usually comes in the form of career, each member of an organization or economy, for example has a unique set of talents, abilities, skills and interests that make them uniquely able to perform a set of tasks. Storper (2014) agreed that organizational training exploits these unique talents and places people in areas where they perform the best, helping both the individual as well as the overall economy. If for example, a single individual excels at math but is not a proficient writer, it benefits both the individual and the community if they pursue a field that relies heavily on mathematics. Niederhoffer (2013) agreed that training allows job specialization which is the separation of jobs up into parts usually performed by different individuals. Zysman (2017) agreed that when specialization is subsumed in economics as increasing returns to scale, and the great improvement in output or profits that come from continuing until variable costs are more than the marginal costs without regard to the high fixed costs in many processes. Williams (2014) agreed that increasing the specialization leads to enhanced output from improvements in the productivity of labor. A major reason that specialization works in economics and biology is that everybody is different. According to Helpman (2014) agreeed that not only does everyone have different degrees of aptitudes, and appearance, morphology and physiology, but that everyone's internal organs are different. These differences lead us to be able to perform different tasks with different degrees of efficiency and productivity, and make the benefits of specialization great even when improvements in machinery are not available (Zysman,2017). The main benefits of specialization in training is that one will become proficient at their task because it is small and simple, transfer time between tasks may decrease, the more narrowly defined the job is, the easier it is to develop specialized equipment to assist with the job (Kreps \& Wilson 2014). Conversely, the main problem with specialization is that workers can become bored and dissatisfied. This can lead to higher absenteeism and lower quality of work. It is also possible to overspecialize. Because of the drawbacks of specialization, many firms have sought alternative approaches to designing jobs such as job rotation which involves systematically moving employees from one job to another, global connection encourages rotation of workers to new jobs and possible pay rises for each new job they master. Levinsen (2013) agreed that job enlargement gives employees more tasks to perform while job enrichment attempts to increase both the number of tasks a worker does and the control the worker has over the job. It is more comprehensive than job rotation or job enlargement (Krugman, 2017). Since specialization involves the performance of repetitive production tasks, the work the employees perform may become boring (Wilson, 2014). Depending on the demands of the production cycle on employees, specialization can also lead to job burnout if the company overworks the employees for long periods. Both boredom and burnout can lead to job dissatisfaction and low employee morale. The use of multitasking can prevent this by increasing employee control over the work performed and the opportunity to learn new skills. Rajala(2015) indicated that production settings with units of specialized employees can also cause each unit to turn inward and focus exclusively on its unit goals, while losing sight of overall production goals. This lack of communication between units can hinder production goals and create problems in the production cycle and in the 
products produced. The use of technology can assist in creating more collaboration among units by facilitating the formation of work groups and breaking down the boundaries that can isolate production units (Langlois, 2016). In addition, a business may incur coordination issues due to the effort involved in getting production teams to work effectively, both as a unit and in collaboration with other units. Work teams are another alternative to job specialization. Work is assigned to a team and the team members have control over each worker's duties (Laulajainen, 2015). Temin (2014) agreed that specialization of economic activity within a narrow concentrated set of economic activities is more conducive to knowledge spillovers or if diversity, by bringing together complementary activities, better promotes innovation. Cooper (2013) also agreed that at the individual level, specialization usually comes in the form of career or labor specialization. Each member of an organization or economy, for example, has a unique set of talents, abilities, skills and interests that make her uniquely able to perform a set of tasks. Labor specialization exploits these unique talents and places people in areas where they perform the best, helping both the individual as well as the overall economy.

\section{Conclusions}

The study concluded that competitiveness of an organization depended more on availability of training and development to employees. The training of human resources within an organization is very critical if an organization is to be competitive. Hence training and staff development is very important factor to ensure effective competitiveness of an organization. Organization's knowledge is viewed as the main source of its competitive advantage and knowledge transfer is widely emphasized as a strategic issue for its competitive advantage. Knowledge management is essential in dealing with complex and dynamic business interactions. The study is supported by the resource based view theory which underscores the fact that for organizations to have a competitive advantage in the current dynamic world it has to be innovating to acquire new and unique knowledge resources to improve on their goods and services to overtake competition. The existence of research and development within organizations is a dependable source of acquiring new knowledge which needs to be shared to all employees in an organization to create unity of purpose. Therefore this research significantly contributes to the existing body of knowledge by underscoring the fact that when knowledge is acquired in an organization, it should be well managed to provide competitive advantage to the savings and credit cooperative societies and the national economy at large.

\section{Recommendation}

The study recommended that organizations should invest substantial amount of their budget for training and development programs as they hold important aspects on competitiveness through improved employee knowledge and skills.

\section{Acknowledgement}

I most sincerely thank my supervisor Dr. Nambuswa who is encouraging me to complete my research in time; she is very resourceful in critiquing my drafts. I also acknowledge the assistance from my colleagues with whom we have worked very closely encouraging one another. Other acknowledgements go to my dear wife Alice for her keen interest in this research work and her 
INTERNATIONAL JOURNAL OF ACADEMIC RESEARCH IN BUSINESS AND SOCIAL SCIENCES

Vol. 8, No. 9, Sept. 2018, E-ISSN: 2222-6990 @ 2018 HRMARS

support. I once again acknowledge the moral support received from my loving children. May God bless you.

\section{Corresponding Author}

Alice Siminyu

P. O. Box 1609-30200 Kitale

Email: siminyualice@yahoo.com

\section{References}

Agarwal, R. \& Helfat, C.E (2013). Strategic renewal of organizations Organ. Sci., 20 (2) (2009), pp. 281293

Audretsch, D. \& Caiazza, R. (2016). Technology transfer and entrepreneurship: cross-national analysis. The Journal of Technology Transfer, 41(6), 1247-1259.

Belas, J. \& Gabcova, L. (2014). Reasons for Satisfaction and Dissatisfaction of Bank Customers: Study from Slovakia and the Czech Republic. International Journal of Entrepreneurial Knowledge, 2(1), 4-13.doi: 10.15759/ijek/2014/v2i1/53759

Bellas, J. Cipovova, E. \& Demjan, V. (2014).Current trends in area of satisfaction of banks' clients in the Czech Republic and Slovakia. Transformation in Business \& Economics, 13.3(33), 219-234

Brigham, E. F. \& Houston.(2014). Fundamentals of Financial Management. Interpreting Ali Akbar Yulianto. Jakarta: Four Salemba

Brown, SL. \& Eisenhardt, KM. (2015). Product development: past research, present findings, and future directions. Academy of Management Review 20: 343-378.

Chavan, J.\& Ahmad, F. (2013). Factors Affecting On Customer Satisfaction in Retail Banking: An Empirical Study. International Journal of Business and Management Invention,2(1),55-62

Collis,J. \& Hussey, R. (2014). "Business Research: A Practical Guide for Undergraduate and Postgraduate Students" 4th edition, Palgrave Macmillan, p.54

Creswell, J.W. (2003) .Research design. Sage Publications: Thousand Oaks, CA.

Creswell, J.W. (2009).Research Design:Qualitative, Quantitative and Mixed MethodApproaches. (3rd eds), Sage Publications, London.

Daft, R. (1982). Bureaucratic versus nonbureaucratic structure and the process of innovation and change. In S. B. Bacharach (ed), Research in the Sociology of Organizations (Vol. 1). JAI Press: Greenwich, CT; 129-166.

Drucker, P. F. (2009). Innovative and Entrepreneurship: Practice and Principles. Harper \& Row: New York.

Eisenhardt, K. M. \& Brown, S. L. (2014). Patching: restitching business portfolios in dynamic markets. Harvard Business Review 77: 72-82.

Friedman, T. L. (2007). The World is Flat: A Brief History of the Twenty-First Century. New York: Farrar, Straus and Giroux.

Gholami, M. H., Asli, M. N., Nazari-Shirkouhi, S. \& Noruzy, A. (2013). Investigating the influence of knowledge management practices on organizational performance: an empirical study. Acta Polytechnica Hungarica, 10(2), 205-216. 
INTERNATIONAL JOURNAL OF ACADEMIC RESEARCH IN BUSINESS AND SOCIAL SCIENCES

Vol. 8, No. 9, Sept. 2018, E-ISSN: 2222-6990 @ 2018 HRMARS

Gitomer, J. (2013). Customer Satisfaction is Worthless, Customer Loyalty Is Priceless. Texas: Bard Press.

Hair, J. F., Black, W.C., Babin, B.J. \&Anderson,R.E.(2010).Multivariate Data Analysis: A Global Perspective. Upper Saddle River, NJ: Pearson.

Helfat, D.(1997).Dynamic Capabilities and Strategic Management. Strategic Management Journal, 18(7): 509-533.

Herington, C. \&Weaven, S. (2009). E-retailing by banks: E-service quality and its importance to customersatisfaction. EuropeanJournalofMarketing, 43(9),12201231.doi:10.1108/03090560 910976456.

Islam, Z., Low, K. C. \& Hasan, I. (2011). Knowledge management practices and organizational effectiveness: Empirical evidence from banks of an underdeveloped country.

Kothari, C. (2010). Research Methodology, Methods and Techniques. New Delhi: WileyEaston.

Kothari, C. (2014). Research Methodology, Methods and Techniques. New Delhi: Wiley Easton.

Lippman, S.A. \& Rumelt, R.P. (2015). Uncertain imitability: an analysis of interfirm differences in efficiency under competition Bell J. Econ., 13 (2) (1982), pp. 418-438.

Miller, D. Fern, M. \& Cardinal, L. (2013). The use of knowledge for technological innovation within diversified firms. Academy of Management Journal 50: 308-326.

Moazzam, A. (2014).Sampling and sample size estimation. World Health Organization Geneva, Switzerland. Presented at GFMER.

Mwita, M. (2016). Mobile phone service firms fail quality test.

Ngwiri, K., Mukulu, S.K,\& Mbuthia, M. (2016). Knowledge management: an introduction and perspective. Journal of knowledge Management, 1(1), 6-14.

Rudez, H. (2010). Knowledge management in the hotel industry before and after the entry in the EU: the case of Slovenia. Organizacija, 43(4), 197-201.

Rumelt,R.P.(2014).Good Strategy/Bad Strategy: the Difference and Why it Matters Crown Business, New York (2011).

Saunders, M. (2009). Research Methods for Business Students. Harlow: Financial Times Prentice Hall. Saunders, M. Lewis, P. \& Thornhill, A. (2012). "Research Methods for Business Students" 6th edition, Pearson Education Limited.

Sekaran, U. (2003). Research methods for business: A skill building approaches. New York. PrenticeHall.

Sekaran, U. Delahaye, B.L. \& Cavana, R.Y. (2001). Applied business research: Qualitative and quantitative methods. Australia: Wiley \& Sons.

Teece, D. J. Pisano, G.\&Shuen, A. (1990). Firm Capabilities, Resources, and the Concept of Strategy. Center for Research in Management. University of California, Berkeley, CCC Working Paper 90-8.

Teece, D., Peteraf, M. \& Leih, S. (2016). Dynamic capabilities and organizational agility Calif. Manag. Rev., 58 (4) (2016), pp. 13-35

Teece, D. J. (2014).The foundations of enterprise performance: dynamic and ordinary capabilities in an (economic) theory of firms Acad. Manag. Perspect., 28 (4) (2014), pp. 328-352.

Teece, D. J. (2016). Dynamic capabilities and entrepreneurial management in large organizations: toward a theory of the (entrepreneurial) firm Eur. Econ. Rev., 86 (2016) pp. 202-216. 
INTERNATIONAL JOURNAL OF ACADEMIC RESEARCH IN BUSINESS AND SOCIAL SCIENCES

Vol. 8, No. 9, Sept. 2018, E-ISSN: 2222-6990 @ 2018 HRMARS

Teece, D. J. (2007). “Explicating Dynamic Capabilities: The Nature and Microfoundations of (Sustainable) Enterprise Performance," Strategic Management Journal, 28(13): 13191350.

Teece, D. J. (2010). "Technological Innovation and the Theory of the Firm: The Role of Enterprise-level Knowledge, Complementarities, and (Dynamic) Capabilities." In N. Rosenberg and B. Hall (eds.) Handbook of the Economics of Innovation, Volume 1. Amsterdam: NorthHolland.

Wadhwa, A., Kotha, S. (2016). Knowledge creation through external venturing: evidence from the telecommunications equipment manufacturing industry. Academy of Management Journal 49: 819-835. 